1987

\title{
Somber Reflections on the Compulsory Jurisdiction of the International Court
}

Mark Weston Janis

University of Connecticut School of Law

Follow this and additional works at: https://opencommons.uconn.edu/law_papers

Part of the International Law Commons

\section{Recommended Citation}

Janis, Mark Weston, "Somber Reflections on the Compulsory Jurisdiction of the International Court" (1987). Faculty Articles and Papers. 409.

https://opencommons.uconn.edu/law_papers/409 


\section{HEINONLINE}

Citation:

Mark Weston Janis, Somber Reflections on the Compulsory Jurisdiction of the International Court, $81 \mathrm{Am}$. J.

Int'l L. 144 (1987)

Content downloaded/printed from HeinOnline

Mon May 13 10:18:25 2019

-- Your use of this HeinOnline PDF indicates your acceptance of HeinOnline's Terms and Conditions of the license agreement available at https://heinonline.org/HOL/License

-- The search text of this PDF is generated from uncorrected OCR text.

-- To obtain permission to use this article beyond the scope of your HeinOnline license, please use:

\section{Copyright Information}

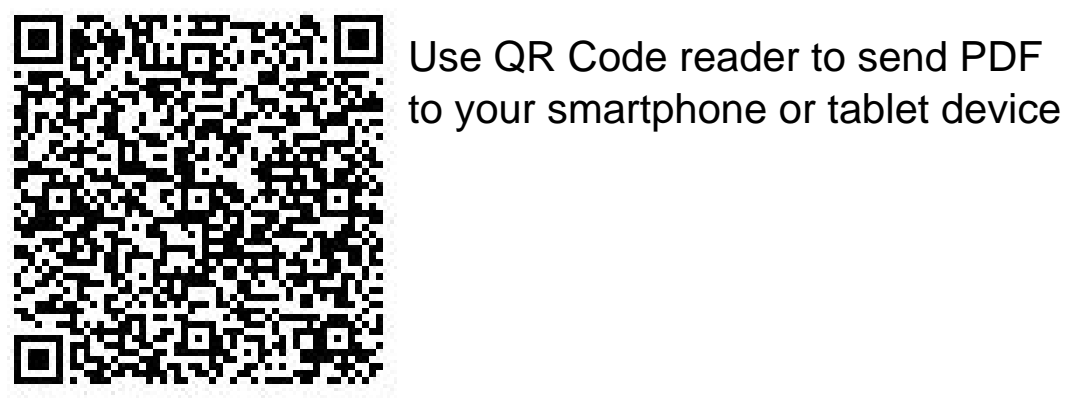




\section{SOMBER REFLECTIONS ON THE COMPULSORY JURISDICTION OF THE INTERNATIONAL COURT}

The Military and Paramilitary Activities case ${ }^{1}$ deepens the glcom already surrounding the two forms of the International Court's compulsory jurisdiction. Neither Article 36(2) of the ICJ Statute, which confers general compulsory jurisdiction upon the Court in cases of reciprocal state declarations, nor that part of Article 36(1) which vests jurisdiction when treaties so provide 2 has been particularly successful in recent practice. No one denies that the ICJ has served a useful, if occasional, role when it has heard and decided cases voluntarily submitted by then-willing states pursuant to the specially conferred provision of Article 36(1). What is in question is the utility of the all too many recent cases where the Court has taken jurisdiction pursuant to the compulsory provisions of its Statute and then has been, to one degree or another, disregarded.

Since 1966, when the ICJ did a volte-face and declined to decide the South West Africa case, ${ }^{3}$ a moment Professor Leo Gross thought the "nadir" of the Court's fortunes, ${ }^{4}$ the ICJ has been considerably more courageous. However, its courage, at least in compulsory jurisdiction cases, has been shown in the face of considerable opposition by states. In the 1970s and 1980s, the Court's compulsory jurisdiction cases have been beset with nonappearing defendants: Iceland in the Fisheries Jurisdiction cases, ${ }^{5}$ France in the Nuclear Tests Cases, ${ }^{6}$ Turkey in the Aegean Sea Continental Shelf case, ${ }^{7}$ Iran in the Diplomatic and Consular Staff case, ${ }^{8}$ and now the United States in the merits phase of the Military and Paramilitary Activities case. ${ }^{9}$

Albeit Article 94(1) of the Charter of the United Nations obliges every state "to comply with the decision of the International Court of Justice in any case to which it is a party," 10 in practice since 1945 states haled into the ICJ by way of compulsory jurisdiction too often have failed to obey adverse court rulings. Albania refused to pay reparations to Great Britain in Corfu Channel, ${ }^{11}$ Iran disregarded the Court's order to refrain from nationalizing

\footnotetext{
${ }^{1}$ Military and Paramilitary Activities in and against Nicaragua (Nicar. v. U.S.), Merits, 1986 ICJ REP. 14 (Judgment of June 27).

${ }^{2}$ Statute of the International Court of Justice, 59 Stat. 1055 (1945), TS No. 993, Art. 36.

${ }^{3}$ South West Africa (Ethiopia v. S. Afr.; Liberia v. S. Afr.) (Second Phase), 1966 ICJ REP. 6 (Judgment of July 18).

${ }^{4}$ Gross, Conclusions, in 2 The Future of the International Court of Jusi"ice 727, 747 (L. Gross ed. 1976).

${ }^{5}$ Fisheries Jurisdiction (UK v Ice.; FRG v. Ice.), Interim Protection, 1972 IC] REP. 12, 30 (Orders of Aug. 17); Jurisdiction of the Court, 1973 ICJ REP. 3, 49 (Judgments of Feb. 2); Merits, 1974 ICJ REP. 3, 175 (Judgments of July 24).

${ }^{6}$ Nuclear Tests (Austl. v. Fr.; NZ v. Fr.), 1974 ICJ REP. 253, 457 (Judgments of Dec. 20).

7 Aegean Sea Continental Shelf (Greece v. Turk.), 1978 ICJ REP. 3 (Judgment of Dec. 19).

${ }^{8}$ United States Diplomatic and Consular Staff in Tehran (U.S. v. Iran), 1979 ICJ REP. 7

(Order of Dec. 15); 1980 ICJ REP. 3 (Judgment of May 24).

${ }^{9} 1986$ ICJ REP. 14.

${ }^{10}$ UN CharTER, 59 Stat. 1031 (1945), TS No. 993, art. 94(1).

${ }^{11}$ Corfu Channel (UK v. Alb.), Merits, 1949 ICJ REP. 4 (Judgment of Apr. 9).
} 
a British corporation pending a final judgment of the Court or agreement between the parties in Anglo-Iranian Oil Co., ${ }^{12}$ Iceland refused to obey an order not to enforce a 50-mile fishing zone until the Court ruled on suits brought by West Germany and the United Kingdom in Fisheries Jurisdiction, ${ }^{13}$ Iran rejected the Court's Order and Judgment that it release the American hostages in Diplomatic and Consular Staff, ${ }^{14}$ and the United States has now declared that it will ignore the Court's ruling in Military and Paramilitary Activities. ${ }^{15}$ There is always the theoretical possibility of enforcing an ICJ judgment against a recalcitrant state by having the Security Council take action, ${ }^{16}$ but in practice this has not occurred. ${ }^{17}$ What gain is there in disregarded compulsory jurisdiction cases?

Almost three decades ago, Sir Hersch Lauterpacht concluded that the Court was much more useful as a vehicle for developing the rules of international law than it was as a means of maintaining international peace. ${ }^{18}$ Certainly, there is grist for many legal mills in the language of even ineffective compulsory jurisdiction cases, Military and Paramilitary Activities being no exception. The majority opinion alone has new and very illuminating language about, inter alia, nonappearing parties, ${ }^{19}$ the proof of facts in international law, ${ }^{20}$ the relationship of treaty law and customary international law, ${ }^{21}$ and aggression and self-defense. ${ }^{22}$

There may also be some public relations value in otherwise ineffective compulsory jurisdiction cases. The United States, for example, sought to use the Diplomatic and Consular Staff case as a means of maintaining "support for the American position by the vast majority of nations on earth,"23 although it is doubtful the ICJ was ultimately so useful in freeing the hostages as were the economic sanctions taken against Iran. ${ }^{24}$ In the Military and Paramilitary Activities case, it is far too early to tell whether Nicaragua will

12 Anglo-Iranian Oil Co. (UK v. Iran), Interim Protection, 1951 ICJ REP. 89 (Order of July 5).

19 1972 ICJ REP. 12, 30.

141979 ICJ REP. 7; 1980 ICJ REP. 3.

${ }^{15}$ I986 ICJ REP. 14; see The Times (London), June 28, 1986, at 1.

16 UN CHARTER, supra note 10, art. 94(2), which reads in full:

If any party to a case fails to perform the obligations incumbent upon it under a judgment rendered by the Court, the other party may have recourse to the Security Council, which may, if it deems necessary, make recommendations or decide upon measures to be taken to give effect to the judgment.

${ }^{17}$ In Diplomatic and Consular Staff, before the Judgment came down, the Soviet Union had already vetoed a U.S. proposal to the Security Council to impose an economic boycott against Iran. There were 10 votes in favor, 2 against, 2 abstentions and 1 not voting. UN Doc. S/PV.2191/Add.1, at 54-55 (1980). The United States never asked the Security Council to enforce the Court's Judgment. In the Military and Paramilitary case, the United States vetoed Security Council action.

${ }^{18} \mathrm{H}$. LAUTERPACHT, THE DEVELOPMENT OF INTERNATIONAL LAW BY THE INTERNATIONAL COURT 4-5 (1958).

${ }^{19} 1986$ ICJ REP. at 23-26, paras. 26-31. $\quad{ }^{20} I d$. at 38-45, paras. 57-74.

${ }^{21} \mathrm{Id}$. at 92-97, paras. 172-82. $\quad{ }^{22} \mathrm{Id}$. at 97-117, paras. 183-225.

${ }^{29}$ President Carter, Address of Jan. 8, 1980, DeP'T ST. Bull., March 1980, No. 2036, at 33.

${ }^{24}$ See Janis, The Role of the International Court in the Hostages Crisis, 13 CoNN. L. REv. 263 (1981). 
be any more successful in its attempt to use the Court's Judgment to sway public opinion in the United States and in other states. ${ }^{25}$

Against such gains must be weighed the loss in respect for the ICJ when it acts like a court in name but not in deed. These cases of compulsory jurisdiction display the Court in its weakest and least effectual role. In these circumstances, the ICJ does not truly adjudicate disputes, if "adjudication" has anything to do with a decision that actually settles a matter.

Plainly, much of the blame for the loss in respect for the Court rests on the shoulders of noncomplying defendant states that are failing to observe Article 94(1) of the Charter. Some fault, too, lies with applicant states that use the Court as a public forum when they know that the ICJ has little practical chance of effectively resolving a dispute. Realistically, it may be time for us to recognize that, given the present context of world politics, the compulsory jurisdiction provisions of the ICJ Statute are simply overoptimistic and that the surer and better role for the Court is in the adjudication of cases jointly submitted by willing states. It may be time, too, for the ICJ to contemplate a strategic retreat and in cases of compulsory jurisdiction to be willing to contemplate a doctrine of judicial restraint when it seems unlikely that its decisions will be respected in practice.

MARK WeSTON JANIS*

\section{Custom on a Sliding Scale}

Every student who has ever taken a traditional international law course has learned Manley Hudson's four elements for the emergence of a rule of customary international law:

(a) concordant practice by a number of States with reference to a type of situation falling within the domain of international relations;

(b) continuation or repetition of the practice over a considerable period of time;

(c) conception that the practice is required by, or consistent with, prevailing international law; and

(d) general acquiescence in the practice by other States. ${ }^{1}$

In the give-and-take of international relations, and in the jurisprudence of the International Court, these elements have been compressed into two: consistent state practice and Hudson's third element, the opinio juris. ${ }^{2}$ In

\footnotetext{
${ }^{25}$ For some of the public relations efforts of Nicaragua with respect to the Court's Judgment, see The Times (London), July 28, 1986, at 5; and $i d$., July 30, 1986, at 5.

* Professor of Law, University of Connecticut.

1 [1950] 2 Y.B. INT'L L. COMM'N 26, UN Doc. A/CN.4/SER.A/1950/Add.1.

${ }^{2}$ See especially North Sea Continental Shelf Cases (FRG/Den.; FRG/Neth.), 1969 ICJ REP. 3, 41-44 (Judgment of Feb. 20).
} 